\title{
Analyzing the Corrosion Behaviour of Cu doped ZnO Nanomaterials on Mild Steel in NaCl Solution
}

\author{
S. Subhasree \\ Department of Chemistry, Government College of Engineering, \\ NH 44, Karuppur, Salem, Tamilnadu -636011, India
}

\begin{abstract}
The present work focuses on the synthesis of Pure and Copper doped Zinc oxide nanocomposites using the extraction of Ocimum sanctum. The nanocomposites were characterized using Fourier transform infrared spectroscopy (FT-IR), X-ray Diffraction (XRD), Field emission scanning electron microscopy (FE-SEM), Energy Dispersive X-ray Analysis (EDAX). A methodical processing has been conducted on the result of $\mathrm{Cu}$ doped $\mathrm{ZnO}$ nanocomposite for the anticorrosion performance on the mild steel. The dimension of the proposed nanocomposites found to be $38 \mathrm{~nm}$ and was coated on mild steel in nickel bath solution. The corresponding anticorrosion on the coated mild steel was investigated in 3.5\% $\mathrm{NaCl}$ solution by performing potentiodynamic polarization measurement and electrochemical impedance spectroscopy respectively. The surface morphology of the coated mild steel engrossed in corrosive solution was studied by SEM with EDAX. The $\mathrm{Cu}-\mathrm{ZnO}$ nanocomposites coating has shown an ideal shield against corrosion and the defensive capability lye in the range of 95\%. The prepared nanocomposites of $\mathrm{Cu}-\mathrm{ZnO}$ nanocomposites have improved the process of mild steel in all corrosion media are subjected to further investigations in order to improve the quality of the composite for anticorrosion applications.
\end{abstract}

KEYWORDS: $\mathrm{Cu}-\mathrm{ZnO}$ nanocomposite, Electrodeposition, Potentiodynamic Polarization Measurement, Electrochemical impedance spectroscopy. Mild steel, $\mathrm{NaCl}$ Electrolyte.

https://doi.org/10.29294/IJASE.8.3.2022.2274-2282

(C2022 Mahendrapublications.com, All rights reserved

\section{INTRODUCTION}

The nanotechnology is an essential and multifaceted field of the hour. The distinctive optical and electrical properties of Copper doped Zinc oxide nanocomposites like broad band gap of $3.37 \mathrm{eV}$, large exciton binding energy of $60 \mathrm{meV}$ and high electron mobility at room temperature is proper for new function and devices. In recent times, customized Copper doped Zinc oxide are prepared by doping with transition metals doped as $\mathrm{Ag}$ [1], $\mathrm{Mn}[2], \mathrm{Fe}[3], \mathrm{Co}[4], \mathrm{Cr}[1], \mathrm{Al}[6]$ and $\mathrm{Pd}[7]$. The outcome of these transition metal doped Zinc oxide show that the optical, magnetic and electrical properties altered with the change in concentration of transition metal. Electronic conductivity of Copper is far above the expected value and it is inexpensive and massively available on Earth's crust and therefore it is important metal for doping [8]. The doping of Copper in Zinc oxide is expected to modify absorption and other physical or chemical properties. Nano $\mathrm{ZnO}$ is harmless, with extensive band gap has also been identified as a shows potential semiconductor material for exhibiting ferromagnetism (RTFM) at room temperature, when doped with most of the transition metal elements [9]. The change over metal doped nanostructures in an effectual method to adjust the energy level surface states of $\mathrm{ZnO}$, which can further get better by the changes in doping concentrations of doped material and hence its physical and especially optical properties [10] . In current days, the sole properties established in Copper doped Zinc oxide nanocomposites have attracted great interest for developing a wide range of advanced applications including field effect transistors [11,12] field emission arrays, ultraviolet lasers, light emitting diode [13] sensors, biosensors [14,15] catalyst $[16,17]$ energy storage and solar cell [18]. The complex functional properties of nanostructure materials are closely related to several features such as high surface mass ratio, selective control surface terminal, different local structure from bulk, magnetic property and also electronic structure. All these factors can be controlled by modifying the nanostructures and most of obtained nanostructure materials obey the specific synthesis method and conditions.

Oxidization of metals is a major crisis which causes huge financial losses to petroleum, aerospace and automotive industries. Mild steel is a well known for its low price and has a noble potential, but it loses its characteristics property when rust occurs in seawater and chloride environment. Rust resistance analysis of aluminium-doped zinc oxide layers deposited by 
pulsed magnetron sputtering [19]. An effort was made to investigate the coating on mild steel containing $\mathrm{Cu}$ doped $\mathrm{ZnO}$ nanocomposites in improving its life. $\mathrm{Cu}$ doped $\mathrm{ZnO}$ nanocomposites were prepared by environmental method and used for fabrication of $\mathrm{Cu}-\mathrm{ZnO}$ Nanocomposite coating on mild steel. The particles were characterized by FTIR, XRD, and FESEM with EDAX analysis. Surface morphology of the coated materials was studied by FESEM and EDAX images. The Corrosion behaviour of the coatings was investigated by Tafel, electrochemical impedance spectroscopic studies.

\section{MATERIALS AND METHODS \\ 2.1 Chemicals}

Ocimum sanctum leaves were collected from local agriculture fields, Salem. Tamilnadu. India. Zinc acetate $\left(\mathrm{Zn}\left(\mathrm{CH}_{3} \mathrm{COO}\right)_{2}\right)$ and Copper acetate $\left(\mathrm{Cu}\left(\mathrm{CH}_{3} \mathrm{COO}\right)_{2}\right.$ and citric acid $\left(\mathrm{C}_{6} \mathrm{H}_{8} \mathrm{O}_{7} \cdot \mathrm{H}_{2} \mathrm{O}\right)$ was purchased from Ranbaxy fine Chemicals and $\mathrm{Na}_{2} \mathrm{CO}_{3}$ from ADLAB Chemicals used as such without further purifications.

\subsection{Synthesis of Copper doped ZnO Nanoparticle using Ocimum Sanctum Leaf Extract}

Ocimum sanctum leaves were used by washing it in distilled water, dirt's are removed like scum, dust from the de-ionized water. Then it was allowed to dry at $30 \mathrm{C}$, a sample of $15 \mathrm{~g}$ was taken for nanomaterials synthesis and boiled with 150 $\mathrm{ml}$ of de-ionized water for $15 \mathrm{~min}$ at $80^{\circ} \mathrm{C}$. A light greenish yellow colored solution was formed followed by cooled at room temperature then by decanting the greenish yellow colour extraction. A solution of Zinc acetate and Copper acetate with citric acid was produced in de-ionized water by stirring continuously for about $2 \mathrm{~h}$ by using magnetic stirrer and then added in plant extract drop by drop, thereafter is adding up of sodium carbonate solution, a grey color precipitate was formed at $\mathrm{pH} 6$. The collected precipitate washed and dried for nearly 10 days followed by the $10^{\text {th }}$ day, light grey colour material was obtained that was crushed and powdered using pestle and heated at $600^{\circ} \mathrm{C}$ for $2 \mathrm{~h}$. The resultant pure grey powdered product of Copper doped $\mathrm{ZnO}$ Nps was attained.

\subsection{Preparation of Specimen}

The substrate of dimension $1 \mathrm{x} \mathrm{cm}^{2}$ was cut and used for corrosion studies. The emery paper was used to smoother the surface of the metal coupons so that the existing passive layer was detached.

\subsection{Electrodeposition Process}

Electrodeposition process was performed in a nickel plating bath. As mentioned in Table 1, the analytical grade of $\mathrm{NiSO}_{4}, \mathrm{NiCl}_{2}, \mathrm{H}_{3} \mathrm{BO}_{3}$ was used to prepare the nickel bath electrolyte.

Table 1. Nickel bath electrolyte

\begin{tabular}{|l|l|}
\hline Composition & Concentration \\
\hline $\mathrm{NiSO}_{4}$ & $246 \mathrm{~g} / \mathrm{L}$ \\
$\mathrm{NiCl}_{2}$ & $20 \mathrm{~g} / \mathrm{L}$ \\
$\mathrm{H}_{3} \mathrm{BO}_{3}$ & $40 \mathrm{~g} / \mathrm{L}$ \\
$\mathrm{Cu}-\mathrm{ZnO}$ & $0.1 \quad 0.5 \mathrm{~g}$ \\
$\mathrm{p}^{\mathrm{H}}$ & $4-5$ \\
Temperature & $\mathrm{RT}$ \\
Stirring rate & $350 \mathrm{rpm}$ \\
Time & $30-40 \mathrm{~min}$ \\
Current & $2.5 \mathrm{~mA} / \mathrm{cm}^{2}$ \\
density & \\
\hline
\end{tabular}

The application of electrode position gave a better result of adhesion of coating. Further the throw power was also improved to a great extent including an enhanced cross linking efficiency. The high presentation coating capacity along with superior corrosion resistance attracts the industries to make use of this type of electro deposition [20]. The anode (Ni) and cathode (base material) test cell set up was placed on the magnetic stirring hot plate. The electrolyte $\mathrm{p}^{\mathrm{H}}$ value maintained at 4.5-5.0 to look at the electrodeposition process. The dissimilar deposition time ranging between (30 and $40 \mathrm{~min}$ ) and current density of $2.5 \mathrm{~mA} / \mathrm{cm}^{2}$ was applied. Cleaning the sample with mineral water and drying at surrounding room temperature formed the final mission.

\section{Characterization}

The X-ray diffraction (GE Inspection Technologies, Model No.3003 TT, Make: Germany Operation Voltage: $40 \mathrm{kV}$ Current: $40 \mathrm{~mA}$ ) was used to study the crystal structure of the $\mathrm{Cu}-\mathrm{ZnO}$ Nps. The purposeful group of the mixture experimented by using Fourier Transform infrared spectroscopy (Perking Elmer Model: Spectrum RXI Range: $4000 \mathrm{~nm} \quad-400 \mathrm{~nm}$ ). Morphology, topography and the particle size were differentiated by making use of field emission scanning electron microscope (FESEM). The sample composition was calculated by means of energy dispersive X-ray analysis (EDX) (Make: JEOL, Model: JSM 6390, Japan).

\subsection{FT-IR Analysis}

Fig. 1 depicts the FT-IR spectrum of the prepared $\mathrm{Cu}-\mathrm{ZnO}$. The observed peak at $556 \mathrm{~cm}^{-1}$ in $\mathrm{Cu}$ doped $\mathrm{ZnO}$ confirmed the presence of stretching mode of $\mathrm{ZnO}$ [21]. The broad 
absorption band at $3400 \mathrm{~cm}^{-1}$ was credited to $\mathrm{O}-\mathrm{H}$ stretching, which is assigned to chemisorbed and/or physisorbed $\mathrm{H}_{2} \mathrm{O}$ molecules on the $\mathrm{Cu}-\mathrm{ZnO}$ surface. Another absorption band at $1641 \mathrm{~cm}^{-1}$ is attributed to $\mathrm{H}-\mathrm{O}-\mathrm{H}$ bending vibration that was assigned to a small amount of $\mathrm{H}_{2} \mathrm{O}$ in the $\mathrm{Cu}-\mathrm{ZnO}$ nanoparticles [22]. The $\mathrm{C}=0$ band was experimented at $1416 \mathrm{~cm}^{-1}$. The band at $877 \mathrm{~cm}^{-1}$ proved the presence of $\mathrm{Zn}-\mathrm{Cu}-\mathrm{O}$ [23].

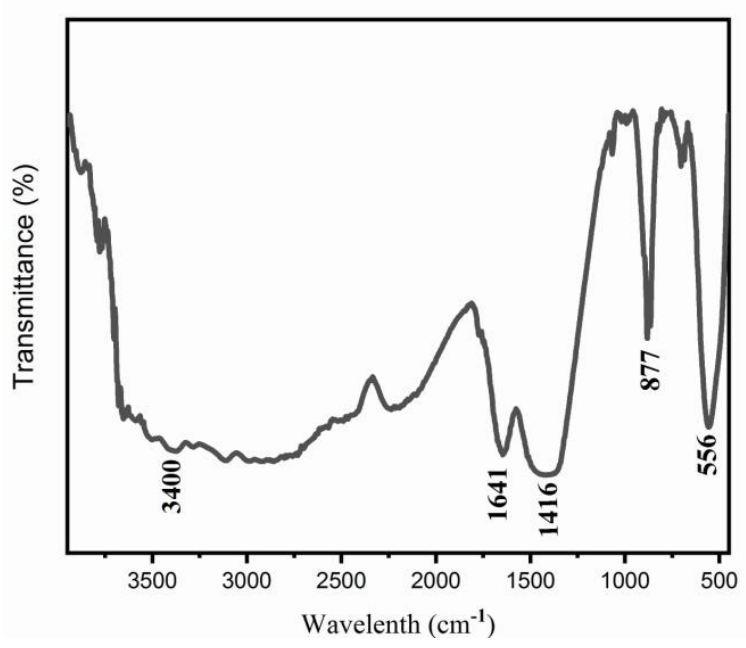

Fig. 1 FT-IR spectrum of Copper doped Zno Nps

\subsection{XRD Analysis}

The XRD patterns of the synthesized copper doped $\mathrm{ZnO}$ sample are shown in Fig. 2. All the diffraction peaks at 31.5, 34.2, 36.1, 47.3, 56.4, 62.6 and 67.8 corresponds to planes of (100), (002), (101), (102, (110), (103) and (112) respectively. All the diffraction peaks were readily indexed for the hexagonal wurtzite structure found in the standard JCPDS card No. 36-1451 [24]. It was clearly noticed that the reflection peaks became sharper with increasing doping concentration and showing the enhancement of crystallinity. In addition, the nonexistence of other peak shows that no other elements were present in the sample [25]. The planes corresponding to different diffraction peaks have been found out by estimating the average particle size and lattice parameters were calculated using the equations (1) , (2) and (3) [26].

$$
\begin{aligned}
& a=\lambda /\left(3^{1 / 2} * \sin \theta_{100}\right) \\
& c=\lambda /\left(\sin \theta_{002}\right) \\
& D=0.9 \lambda /(\beta \cos \theta)
\end{aligned}
$$

Where, $\lambda$ - Wavelength of X-ray

$\theta$ - Bragg angle of the diffraction peak

D - Mean crystalline size of particles

B - Full-width at half-maximum intensity respectively.
The element size was calculated from XRD diffraction peaks using the Scherrer formula, it was observed that its size approximately 38.64 $\mathrm{nm}$. Therefore the expected particle size matched with the particle analyzed value (40.16 nm). According to the Scherrer formula, the particle size of $\mathrm{Cu}$-doped $\mathrm{ZnO}$ is $38 \mathrm{~nm}$. The copper peak is not noticed after doping since the doped copper entered the zinc oxide structure $[27,28]$.

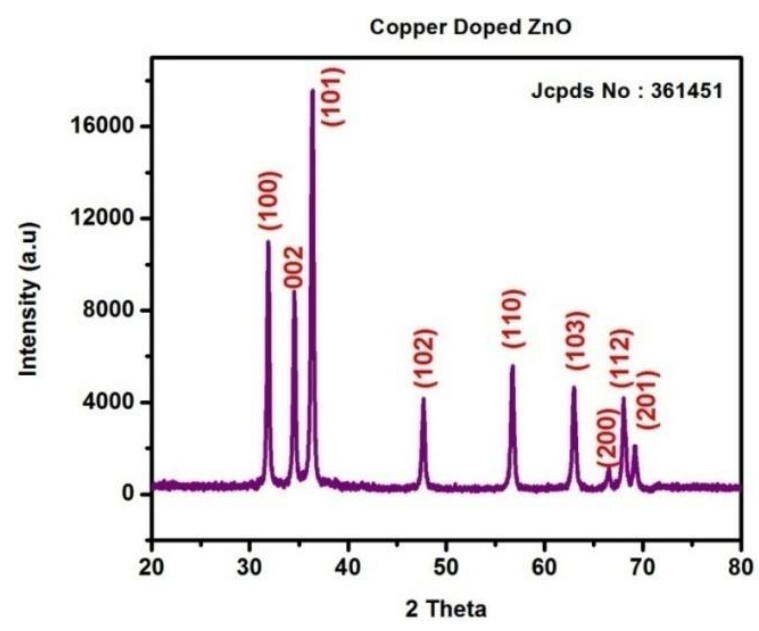

Fig. 2 XRD diffraction spectra of copper doped ZnO NPs

\subsection{FE-SEM \& EDX Analysis}

The Fig. 3(a) and 3(b) shows SEM images exposed that the individual particles were composed by the collection of particles of different shapes with raise in the $\mathrm{Cu}$ concentration. This represents that doping of $\mathrm{Cu}$ ions influence robustly on morphology of ZnO Nanoparticles. The synthesized nanoparticles are harmonized, consistently distributed over the surface and good connectivity between the particles that contained the mixer of spheroid-like and rod-like particles that were below $200 \mathrm{~nm}$. The SEM indicated the size and shape of the ZnO nanoparticles depend on the $\mathrm{Cu}$ additive. This conclusion was found in close agreement with previous reports [29].
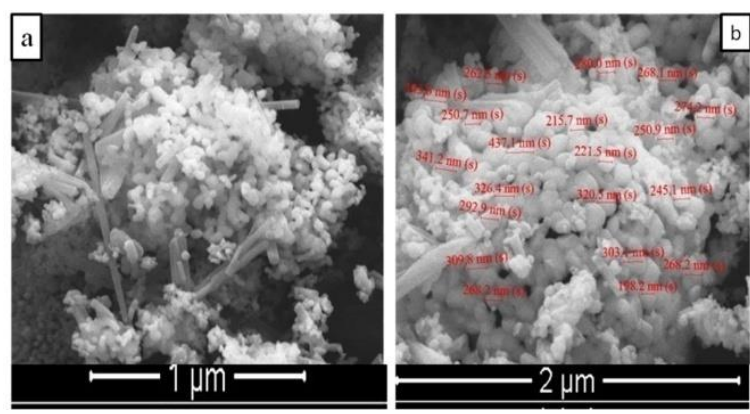

Fig 3 (a) FE-SEM image of Copper doped ZnO Nps $1 \mu \mathrm{m}$ (b) $2 \mu \mathrm{m}$ 


\section{RESULTS AND DISCUSSION 4.1 Potentiodynamic Polarization Measurements}

The corrosive character of the nanocoating was estimated by the polarization data that was derived from $3.5 \% \mathrm{NaCl}$ electrolyte. In the open circuit potential the deposits was polarized at $\pm 200 \mathrm{mV}$. Fig.4 depicts the polarization graphs. The electrochemical corrosion kinetic parameter, corrosion potential ( $\left.E_{\text {corr }}\right)$ cathodic and anodic Tafel slopes ( $b_{a}$ and $b c$ ) are given in Table II. Corrosion potential ( $E_{\text {corr }}$ ) of mild steel in 3.5\% $\mathrm{NaCl}$ electrolyte found to be $-1.017 \mathrm{~V}$ and the standards for $\mathrm{Cu}-\mathrm{ZnO} \mathrm{Nps}$ coated mild steel was \pm $85 \mathrm{mV}$ representing the mixed type inhibitor. Corrosion current ( $\mathrm{I}_{\text {corr }}$ ) readings reduce with rising concentration of nanocoating on mildsteel. This represented that coating of $\mathrm{Cu}-\mathrm{ZnO} \mathrm{Nps}$ inhibits the corrosion rate. The following equation calculates the rate of corrosion:

$\mathrm{CR}($ mils $/ \mathrm{y})=\left(3.27 \times 10^{-3}\right) \mathrm{I}_{\mathrm{corr}}($ Eq.wt. $) / \mathrm{dx} 0.0254$ (4)

Where, the Eq.wt refers to the equivalent weight of mild steel (28.25), d being the density of the mild steel $\left(7.85 \mathrm{~g} / \mathrm{cm}^{3}\right)$. The corrosion rate of mild steel in $3.5 \% \mathrm{NaCl}$ electrolyte was found to be 48.21 mpy. The rust speed of $\mathrm{Cu}-\mathrm{ZnO}$ Nps covered mild steel was less than the uncovered metals.

The efficiency of inhibition computed using the formula

$$
\left.\mathrm{IE} \%=\left(\mathrm{I}_{\text {corr }}-\mathrm{I}_{\text {corr }}\right) / \mathrm{I}_{\text {corr }}\right) \times 100
$$

Where I'corr and I corr are the present rusting values of metal in presence and in absence of $\mathrm{Cu}$ ZnO Nps coating. The inhibition efficiency maximum at $95.01 \%$ for $3.5 \% \mathrm{NaCl}$ with $0.5 \mathrm{~g} \mathrm{Cu}-$ ZnO Nps was achieved. It was observed that the increase of the efficiency in the inhibition that corresponded with the raise of nanocoating concentration. In the same way, the inhibition efficiency condensed along the raise in the denseness of aggressive medium. This could be because of the dispersal of corrosive chloride ions through the nanocoating. Subsequently, the next inspection is that the inhibition efficiency also reduced with the more concentration of $\mathrm{Cu}-\mathrm{ZnO}$ Nps above 0.5g. The weak adhesion of Nps resulted largely because of collection at high concentration leading to weak deposition.

Table II. Polarization parameters of mild steel coated $\mathrm{Cu}-\mathrm{ZnO} \mathrm{Nps}$ in $\mathrm{NaCl}$.

\begin{tabular}{|c|c|c|c|c|c|c|}
\hline 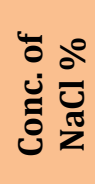 & 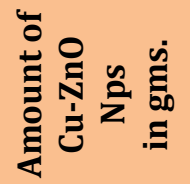 & 氖 & 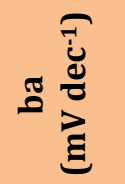 & 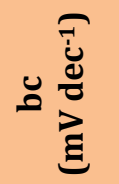 & 을 & 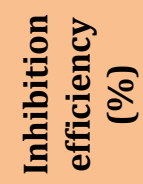 \\
\hline \multirow{6}{*}{3.5} & Blank & -1.017 & 164.06 & 211.77 & 117.20 & -- \\
\hline & 0.1 & -0.996 & 136.70 & 334.11 & 68.13 & 41.86 \\
\hline & 0.2 & -0.947 & 200.24 & 260.07 & 51.04 & 56.45 \\
\hline & 0.3 & -0.963 & 183.58 & 140.50 & 33.61 & 71.32 \\
\hline & 0.4 & -0.981 & 88.69 & 524.10 & 19.51 & 83.35 \\
\hline & 0.5 & -0.941 & 96.97 & 225.78 & 5.84 & 95.01 \\
\hline
\end{tabular}
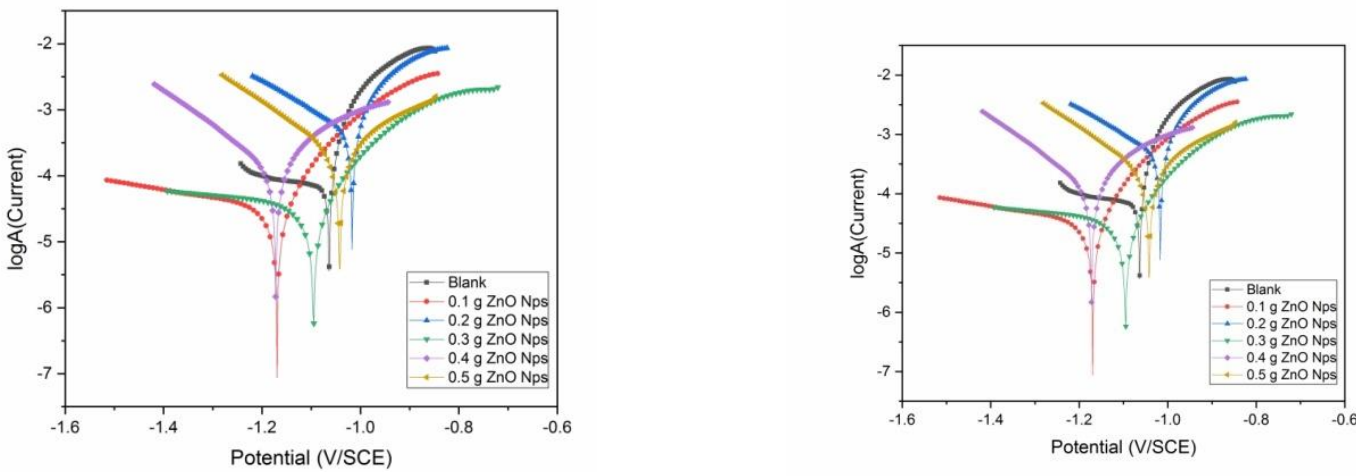

Fig. 4 Potentiodynamic curves for mild steel with various concentrations of $\mathrm{Cu}-\mathrm{ZnO} \mathrm{Nps}$ in $3.5 \% \mathrm{NaCl}$

\section{Subhasree}




\subsection{Impedance Measurements}

Fig. 5 show the impedance measurements (EIS) carried out at $5 \mathrm{mV}$ with a frequency range of 100 $\mathrm{kHz}$ to $10 \mathrm{mHz}$. The Nyquist plots presented the EIS values for suitable equivalent circuit that comprises of solution resistance identified as $\left(R_{s}\right)$ followed by coating capacitance noted as ( $\left.Q_{\text {coat }}\right)$, next is coating resistance marked as ( $\mathrm{R}_{\text {coat }}$ ), succeeded by double layer capacitance recognized as $\left(Q_{\mathrm{dl}}\right)$ end with the charge transfer resistance which is understood as ( $\left.\mathrm{R}_{\mathrm{ct}}\right)$. Zsimpwin 3.21software was used for this purpose and presented in Table III. The Constant Phase Element (CPE), a sign of the non-ideal homogeneity of the surface, replaced the capacitor.

$$
Z_{C P E}=Y_{0}^{-1}(i \omega)^{-n}
$$

In the above equation $\mathrm{Y}_{0}$ represents the CPE which is a constant, $\mathrm{i}^{2}=-1$ is an imaginary number, $\omega$ is the angular frequency and $n$ indicates the CPE component that gives the particulars related to the degree of homogeneity on the metal surface, micro-roughness and probity. The corrosion inhibition efficiency can be computed from the following equation

$$
\mathrm{IE} \%=\frac{\mathrm{R}_{\mathrm{p}}-\mathrm{R}_{\mathrm{p}}^{\prime} \mathrm{R}}{\mathrm{Rp}} 100(7)
$$

Where $R_{p}^{\prime}$ and $R_{p}$ represent the polarization resistance values of metal free coating with $\mathrm{Cu}$ -
ZnO Nps coating respectively. The $Q_{\mathrm{dl}}$ values steadily decreased for mild steel after the inclusion of $\mathrm{Cu}-\mathrm{ZnO} \mathrm{Nps}$ from $0.1 \mathrm{~g}$ to $0.5 \mathrm{~g}$. It was observed that $0.5 \mathrm{~g}$ of $\mathrm{Cu}-\mathrm{ZnO} \mathrm{Nps}$ layer on metal (mild steel) was optimum in $3.5 \% \mathrm{NaCl}$ electrolyte. The minimum of $\mathrm{Q}_{\mathrm{dl}}$ value was observed for $0.5 \mathrm{~g}$ in $3.5 \% \mathrm{NaCl}$. Similarly, higher $\mathrm{R}_{\mathrm{ct}}$ value for mild steel and $\mathrm{Cu}-\mathrm{ZnO} \mathrm{Nps}$ coating showed excellent corrosion resistance property without outside layer. The decrease in $Q_{\mathrm{dl}}$ and increase in $\mathrm{R}_{\mathrm{ct}}$ value for Mild steel coated with $\mathrm{Cu}$ ZnO Nps denotes an increased obstruction among the interface of electrolyte and Mild steel. The coated metal surface made a better stability and a insufficient amount of pores on its exterior area, resulting in a reduction of corrosion reactions on the surface of electrode. The mild steel with $0.5 \mathrm{~g}$ $\mathrm{Cu}-\mathrm{ZnO} \mathrm{Nps}$ coating registered a high impedance value. The output showed the maximum inhibition efficiency of 96.20 in $3.5 \% \mathrm{NaCl}$ electrolyte respectively. The higher the Nps thickness, the lower is the impedance value. This is due to the gathering of Nps on mild steel during its coating which results in poor adhesion and porous deposits; as a result there was a decrease in impedance. Furthermore, decrement in impedance at higher concentration of $\mathrm{NaCl}$ electrolyte is due to the diffusion of chloride ions through nanocoating. The diffusion of chloride ions was proportional to its solution pressure which weakens the adhesion. The EIS outcome disclosed a superior corrosion resistance property of mild steel $\mathrm{Cu}-\mathrm{ZnO} \mathrm{Nps}$ coating.

\begin{tabular}{|c|c|c|c|c|c|}
\hline 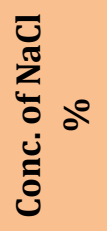 & 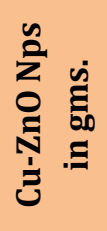 & 苞 & 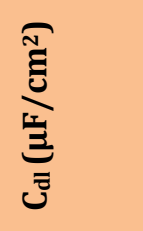 & 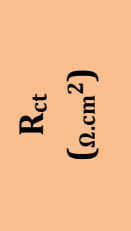 & 递 \\
\hline \multirow{6}{*}{3.5} & Blank & 1041.71 & 1435.95 & 30.06 & -- \\
\hline & 0.1 & 937.20 & 970.13 & 65.54 & 54.13 \\
\hline & 0.2 & 782.96 & 594.69 & 126.85 & 76.30 \\
\hline & 0.3 & 544.37 & 320.91 & 161.94 & 81.43 \\
\hline & 0.4 & 343.70 & 218.11 & 386.33 & 92.21 \\
\hline & 0.5 & 107.00 & 158.61 & 792.30 & 96.20 \\
\hline
\end{tabular}

Table III. Electrochemical impedance data of $\mathrm{Cu}-\mathrm{ZnO}$ Nps coated mild steel in NaCl.

\subsection{Morphology Studies}

Fig.6 (a) shows bare area of the metal (mild steel) and an emery paper used for polishing the surface in the mild steel to eradicate the existing film. Figure 6 (c) shows the plain metal dipped in $3.5 \% \mathrm{NaCl}$ electrolyte kept for $24 \mathrm{~h}$ and the creation of rust on the surface of mild steel. This was caused by the diffusion of $\mathrm{Cl}^{-}$to the mild steel outer area that showed more dissolution of steel in $\mathrm{NaCl}$ medium. Futhermore, It was observed that the exterior area of mild steel had more corrosion patches and porous. $\mathrm{Cu}-\mathrm{ZnO} \mathrm{Nps}$ coated mild steel without immersion is shown in (Fig. 6(b)). The Cu-ZnO Nps coated on the steel after 
immersion for $24 \mathrm{~h}$ in $3.5 \% \mathrm{NaCl}$ electrolyte given (d)), did not show any cracks or defects. The coating appeared more dense and uniform, homogeneous and continuous closed packed structure on mild steel and brought higher corrosion protection to the metallic substrate. It is known that $\mathrm{Fe}_{2} \mathrm{O}_{3}$ are rust composition and $\mathrm{Cu}$ $\mathrm{ZnO}$ forms as a passivation layer on the mild steel. It was examined that $\mathrm{Cu}-\mathrm{ZnO}$ nano coating on metals such as iron gave anodic production and acted as electronic, chemical and physical obstacle to reduce anodic reaction and keep up high opposition to ionic flow. The obstructing the metal dissolution, provide a first-rate rust protection and it prevents electron transfer in $3.5 \% \mathrm{NaCl}$ solution to achieve great corrosion inhibition.

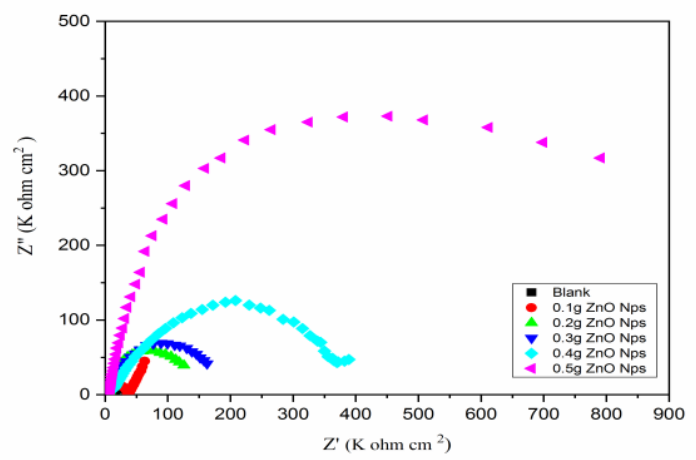

Figure 5

(a) Electrochemical impedance curves for $\mathrm{Cu}-\mathrm{ZnO}$ Nps coated mild steel in $3.5 \% \mathrm{NaCl}$ concentration
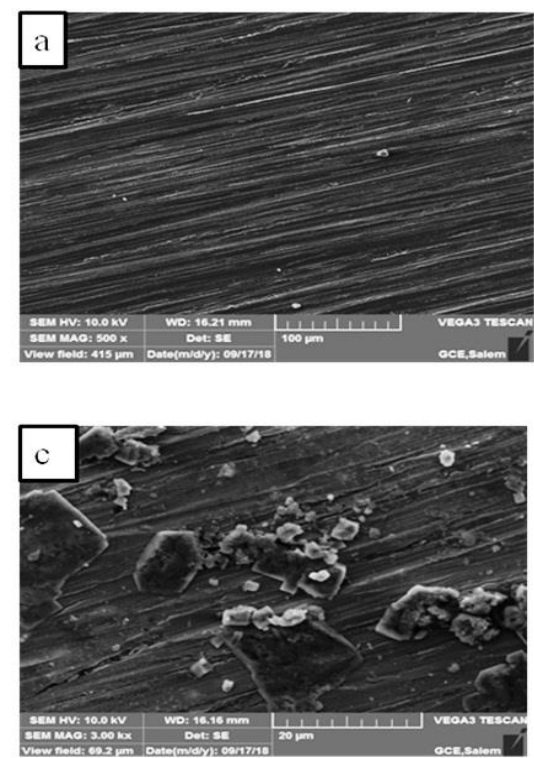

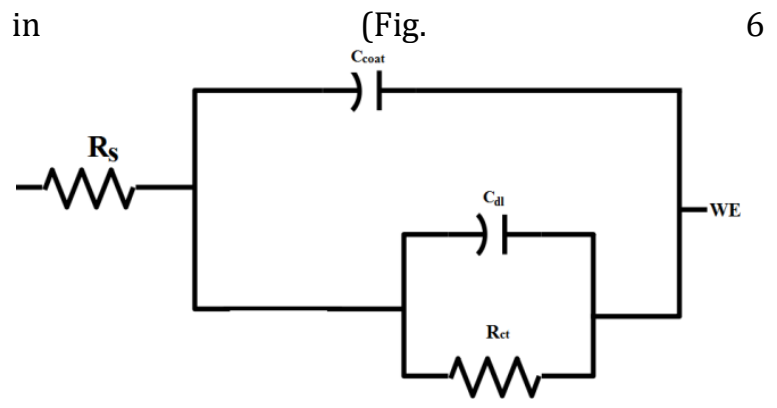

(b) Equivalent circuit describes the schematic of electrochemical reaction.
Rs - Solution resistance of 3.5\%
WE - working electrode
$\mathrm{Q}_{\mathrm{dl}}$ - double layer capacitance
$\mathrm{Q}_{\text {coat }}$ - coating capacitance
Rct- charge transfger resistance
Rcoat - coating resistance

The elemental composition of $\mathrm{Cu}-\mathrm{ZnO}$ nanomaterials was observed by EDX as shown in Fig.7 For the $\mathrm{Cu}-\mathrm{ZnO}$ coated samples, the percentage of $\mathrm{Ni}$ was $4.68 \%$. In the doped samples for the $\mathrm{Cu}$ are observed at $0.71 \%$. In the pure $\mathrm{ZnO}$ the chemical composition is $82.56 \%$ respectively. The EDAX result shows the presence of $\mathrm{Zn}, \mathrm{O}$ and $\mathrm{Ni}$. The prepared nanoparticles are made of these elements. This may be $\mathrm{Cu}^{2+}$ ions incorporated with $\mathrm{Zn}^{2+}$ ion in the $\mathrm{ZnO}$ matrix .
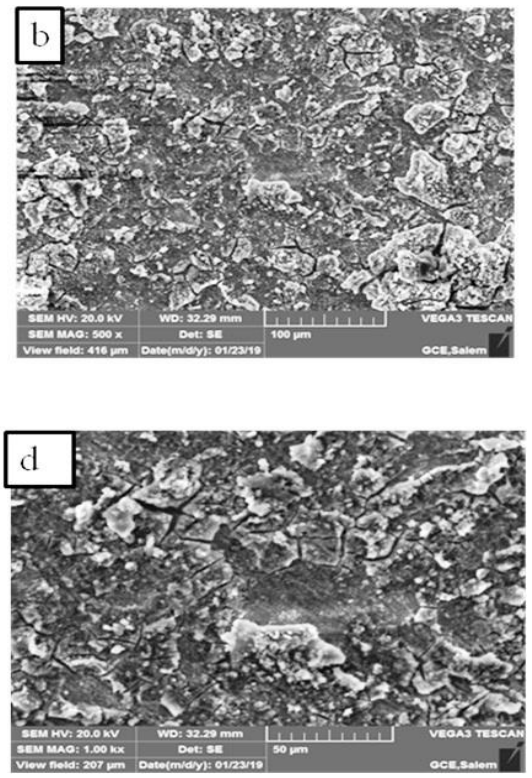

Fig. 6 SEM images of (a) bare mild steel (b) Cu-ZnO Nps coated mild steel (c) bare mild steel immersed in $3.5 \% \mathrm{NaCl}$ solution (d) $\mathrm{Cu}-\mathrm{ZnO} \mathrm{Nps}$ coated mild steel immersed in $3.5 \% \mathrm{NaCl}$.

Subhasree 


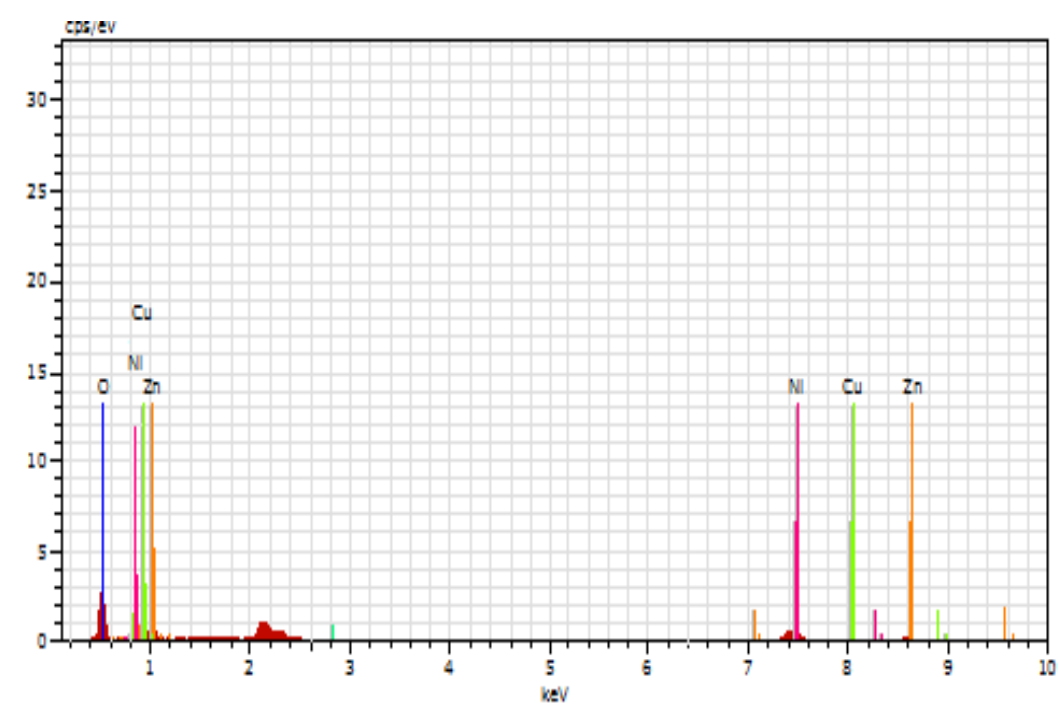

Fig. 7 EDAX pattern of Copper doped ZnO Nps coated mild steel immersed in 3.5\% NaCl electrolyte

\section{CONCLUSION}

The corrosion resistance ability of Nickel Electro deposited $\mathrm{Cu}-\mathrm{ZnO}$ nanocomposite has been systematically studied. It has been inferred that the $\mathrm{Cu}-\mathrm{ZnO}$ composite may minimize alloy reaction within zinc and iron following the formation of inside layer of the mild steel surface leading to asymmetrical and porous surface. The coated layer of $\mathrm{Cu}-\mathrm{ZnO}$ enhanced the adhesion between mild steel and coating layer by inhibiting the dispersion of zinc. The Tafel polarization shows that the compound has a mixed type of inhibition properties. The outstanding functioning of the coating inhibitor has been established from Nyquist plots, where the superior adsorption of the $\mathrm{Cu}-\mathrm{ZnO}$ Nps nanocoating progressively retards $\mathrm{C}_{\mathrm{dl}}$ at the expense of $\mathrm{R}_{\mathrm{ct}}$. Maximum inhibition efficiency was observed at $3.5 \%$ of $\mathrm{NaCl}$ solution with $0.5 \mathrm{~g}$ of $\mathrm{Cu}-\mathrm{ZnO} \mathrm{Nps}$ by both polarization and impedance studies. The SEM and EDAX results assisted in order to agree by its dimension for inhibition efficiency at $3.5 \% \mathrm{NaCl}$ solution. In addition with the above, the impedance studies exposed a maximum inhibition efficiency of $96 \%$ at $3.5 \% \mathrm{NaCl}$ solution and $0.5 \mathrm{~g}$ of $\mathrm{Cu}-\mathrm{ZnO} \mathrm{Nps}$. To support the above mentioned observations the polarization studies confirmed the maximum inhibition efficiency of $95 \%$. Owing to the good performance at corrosive environments, $\mathrm{Cu}-\mathrm{ZnO}$ Nps coating proved the suitability for industrial applications.

\section{REFERENCES}

[1] Fageria, P., Gangopadhya, S., Pande, S.2014. Synthesis of $\mathrm{ZnO} / \mathrm{Au}$ and $\mathrm{ZnO} / \mathrm{Ag}$ nano particles and their photocatalytic application using UV and visible light, RSC Advances, 4, 24962-24972.

[2] Wu, D W., Huang, Z B., Yin, G G., Ya, Y D., Lia, X M., Han, D., Huang, X., Cu, J W. 2012. Preparation, Structure and Properties of Mn-Doped ZnO Rod Arrays. Cryst Eng Comm, 12 (2012) 192-198.

[3] Kaur, J., Kothala, R K., Gupta, V., Verma, K C. 2014. Anionic Polymerization in $\mathrm{Co}$ and $\mathrm{Fe}$ Doped ZnO: Nanorods, Magnetism and Photoactivity. Current Applied physics, 14 (2014) 749-756.

[4] Kuriakose, S., Satpatib, B., Mohapatra, S. 2014. Enhanced Photocatalytic Activity of Co Doped ZnO Nanodisks and Nanorods Prepared by a Facile Wet Chemical Method, Physical chemistry chemical physics, 16,12741-12749.

[5] L,i L., Wang, W., Liu, H., Liu, X., Song, Q., Ren S. 2009. First Principles Calculations of Electronic Band Structure and Optical Properties of $\mathrm{Cr}$-Doped $\mathrm{ZnO}$, The Journal of Physical Chemistry C, 113,8460-8464.

[6] Ahmad, M., Ahmed, E., Zhang, Y W., Khalid, N R., Xu, J F., Ullah, M., Hong, L. 2013. Preparation of Highly Efficient Al-Doped ZnO Photocatalyst by Combustion Synthesis. Current Applied physics, 13, 4697- 704.

[7] Zhong, J B., Li, J Z., He, X Y., Zeng, J, Lu, Y., $\mathrm{Hu}, \quad$ W., Lin, K. 2012. Improved Photocatalytic Performance of Pd-Doped ZnO. Current Applied Physics,12, 990-1001.

[8] Ca F.-F, Xin S, Curo, Y G, Wan, L-J.2011. Wet Chemical Synthesis of $\mathrm{Cu} / \mathrm{TiO} 2$ Nanocomposites with Integrated NanoCurrent Collectors as High Rate Anode 
Materials in Lithium-Ion Batteries. Physical Chemistry Chemical physics, 13, 2014-2020.

[9] Herng, T S., Lau, S P., Yu, S F., Yang, H Y., Wang, L., Tanemura, M., Chen, J S. 2007. Magnetic anisotropy in the ferromagnetic Cu-doped ZnO nanoneedles, Applied Physics Letters, 90, 032509.

[10] Sima, M., Enculescu, I., Enache, M., Vasile, .E., Ansermet, J P.2007. ZnO:Mn:Cu nanowires prepared by template method, Phys Status solido B 244(5)1522.

[11] Karamat, S., Rawat, R S., Tan, T L., Lee, P., Springham, S V., Ani-ur-Rehman, Chen R., Sun, H D.2013. Exciting dilute magnetic semiconductor: copper-doped $\mathrm{ZnO}$, Journal of super conductivity and novel magnetism, (26) 187-195.

[12] Harshida Parmar • Rucha Desai • R.V. Upadhyay, 2011. Structural characterization of microwave-synthesized zinc-substituted cobalt ferrite nanoparticles, J.Sol-Gel Science Technology, 57, 101.

[13] Kim, J B., Byun, D., Ie Sy., Park, D H., Choi, W K., Choi, J-W., Angadr, B. (2008) Cu-doped ZnO-based p-n hetero-junction light emitting diode, Semiconductance Science Technology, 23, 095004.

[14] Chow, L., Lupan, O., Chai, G., Khallaf, H., Ono, LK., Roldan, C B., Tiginyahu, IM., Unsaki, V V., Sontea, V., Scnulte, A. 2013. Synthesis and characterization of $\mathrm{Cu}$-doped $\mathrm{ZnO}$ onedimensional structures for miniaturized sensor applications with faster response, Sensors Actuator A, 189,399.

[15] Zhou, C., Xu, L., Song, J., Xing, R., Xu, S., Liu, D., Song H. 2014. Ultrasensitive nonenzymatic glucose sensor based on threedimensional network of $\mathrm{ZnO}-\mathrm{CuO}$ hierarchical nanocomposites by electrospinning, Science Rep, 4, 7382.

[16] Poonam, B., Anindita, D., Ruma, B., Sukhen, D., Papiya, N. 2014. Synthesis and characterization of copper doped zinc oxide nanoparticles and its application in energy conversion, Current Applied Physics, 14(8) 1149.

[17] Unnikrishnan, R P., Sarojini, D.2006. Copper-zinc oxide and ceria promoted copper-zinc oxide as highly active catalysts for low temperature oxidation of carbon monoxide, Applied Catalyst B, 65,110.

[18] Mohammed, H H., Bahareh., K, Mahmoud, Z., Mehdi H. 2014. Preparation of nanostructure mixed copper-zinc oxide via co-precipitation rout for dye-sensitized solar cells: The influence of blocking layer and $\mathrm{Co}(\mathrm{II}) / \mathrm{Co}(\mathrm{III})$ complex redox shuttle, J.Ind. Eng. Chem, 20, 1462.
[19]

Berasaregui, E G., Bayon, R., Zubizaneta, C,. Bauiga, J., Barros, R., Martins, R., Fortunato, E. 2015. Corrosion resistance analysis of aluminium-doped zinc oxide layers deposited by pulsed magnetron sputtering, Thin Soli films, 594, 256-260.

[20] Deepa, K., Venkatesa, TV. 2018. Combustion synthesis of $\mathrm{Ni}$ doped $\mathrm{SnO}_{2}$ nanoparticles for applications in $\mathrm{Zn}$ composite coating on mild steel, Advanced Materials and Devices, 3(4) 412- 418.

[21] Ashokkumar, M., Muthukumaran, S.2014. Microstructure, optical and FTIR studies of $\mathrm{Ni}, \mathrm{Cu}$ co-doped $\mathrm{ZnO}$ nanoparticles by co-precipitation method, Optical Materials, 37, 671-678.

[22] Manigandan, R., Giribabu, K., Suresh, R., Vijayalakshmi, L., Stephen, A., Narayanan V. 2013. Cobalt Oxide Nanoparticles: Characterization and its Electrocatalytic Activity towards Nitrbenzene, Chemical Science Transactions, 2(1) 47-50.

[23] Labhane, P K., Hvse, R V., Patle, B L., Chaudhari, L A., Sonawane, H G .2015. Synthesis of $\mathrm{Cu}$ Doped ZnO Nanoparticles: Crystallographic, Optical, FT-IR, Morphological and Photocatalytic Study, Journal of Materials Science and Chemical Engineering, 3, 39-51.

[24] Zak B M, Schuksz M, Koyama E, Mundy C, wells D E, Yamaguchi Y, Pacifici M, Esko JD, Compound Heterozygous Loss of Ext1 and Ext2 is sufficient for Formation of Multiple Exostoses in Postnatal Mouse Long Bones in Mice, Journal of Bone, 48 (5) (2011) 979-987.

[25] Rai, S., Tage keith, J., Holyoak, 2013. Exposure to moral relativism compromises moral behavior, Journal of Experimental Social Psychology, 49 (6) 995-1001.

[26] Raoufi, D. 2013. Synthesis and microstructural properties of $\mathrm{ZnO}$ nanoparticles prepared by precipitation method, Renewable Energy, 50 (2013) 932-937.

[27] Ma, Z., Ren, F., Ming, X., Long, Y., Volinsky, A.A. 2019. Cu-Doped ZnO Electronic Structure and Optical Properties Studied by First-Principles Calculations and Experiments, Materials, 12 (1) 196

[28] Hariharan, V., Aroulmoji, V., Prabakaran., K., Karthik, V. 2020. Microwave assisted pure and Mg doped tungsten oxide WO3 nanoparticles for superconducting applications, Int. J. Adv. Sci. Eng. 7(2) 1776-1781 
[29] Khan, S A., Noreen, F., Kanwal, S., Hussain, G, 2017. Comparative synthesis, characterization of $\mathrm{Cu}$-doped $\mathrm{ZnO}$ nanoparticles and their antioxidant, antibacterial,

antifungal

and

photocatalytic dye degradation activities, Digest Journal of Nanomaterials and Biostructures, 12(3) 877-889. 